\title{
Pengaruh Krim Asam Traneksamat terhadap Pembentukan Keriput dan Kadar Matriks Metaloproteinase-1 pada Mencit (Mus Musculus) Jantan Galur Balb/c yang Dipajan Sinar Ultraviolet B
}

\author{
Andrew Citrawan', Oki Suwarsa ${ }^{1,2}$, Hendra Gunawan ${ }^{1,2}$, Sudigdo Adi ${ }^{1,2}$, \\ Ronny Lesmana ${ }^{1,3,4}$, Achadiyani ${ }^{5}$, Sunaryati S. Adi ${ }^{1}$ \\ ${ }^{1}$ Program Studi Pascasarjana Anti-aging dan Aesthetic Medicine, Fakultas Kedokteran, \\ Universitas Padjadjaran, Bandung, Indonesia, ${ }^{2}$ Departemen Ilmu Kesehatan Kulit dan Kelamin, \\ Rumah Sakit Hasan Sadikin, Universitas Padjadjaran, Bandung, Indonesia, ${ }^{3}$ Divisi Fisiologi, \\ Departemen Anatomi, Fisiologi, dan Biologi Sel, Fakultas Kedokteran, Universitas Padjadjaran, \\ Bandung, Indonesia, ${ }^{4}$ Laboratorium Sentral Universitas Padjadjaran, ${ }^{5}$ Divisi Biologi Sel, \\ Fakultas Kedokteran, Universitas Padjadjaran, Bandung, Indonesia
}

\begin{abstract}
Abstrak
Pemberian asam traneksamat (AT) per oral telah terbukti dapat mengurangi keriput yang diinduksi oleh kulit kering pada mencit. Namun, dosis oral yang setara terlalu besar untuk digunakan pada manusia dalam jangka panjang karena dapat menimbulkan toksisitas, sehingga perlu dicari sediaan alternatif lain secara topikal seperti sediaan krim. Penelitian ini bertujuan untuk menganalisis pengaruh pemberian krim AT terhadap pembentukan keriput pada kulit mencit jantan galur Balb/c yang dipajan sinar ultraviolet B (UVB). Penelitian dilakukan terhadap 24 ekor mencit di Laboratorium Farmakologi dan Terapi serta Laboratorium Sentral Universitas Padjadjaran pada bulan Februari hingga Mei 2018. Mencit dibagi secara acak ke dalam empat kelompok, yaitu satu kelompok kontrol $\left(\mathrm{P}_{0}\right)$ hanya mendapatkan pajanan sinar UVB tanpa krim AT dan tiga kelompok perlakuan $\left(\mathrm{P}_{1}, \mathrm{P}_{2}\right.$, dan $\left.\mathrm{P}_{3}\right)$ mendapat pajanan sinar UVB dan diberikan krim AT dengan konsentrasi masing-masing 3\%, 4\%, dan $5 \%$. Setelah 10 minggu, dilakukan penilaian kondisi keriput pada kulit punggung mencit berdasarkan metode Bisett, dilanjutkan dengan biopsi kulit punggung mencit untuk pemeriksaan kadar matriks metaloproteinase-1 (MMP-1) dengan teknik western blot (WB). Diperoleh perbedaan nilai rata-rata skor keriput yang bermakna sebesar $2,1 \pm 0,105$ pada kelompok $\mathrm{P}_{0}, 1,1 \pm 0,167$ pada $\mathrm{P}_{1}$ dan $\mathrm{P}_{2}$, serta $1,3 \pm 0,211$ pada $\mathrm{P}_{3}(\mathrm{p}=0,005)$. Diperoleh pula nilai rata-rata kadar MMP-1 yang bermakna, yakni sebesar $0,75 \pm 0,08$ pada kelompok $\mathrm{P}_{0}$, serta $0,54 \pm 0,033,0,40 \pm 0,052$, dan $0,54 \pm 0,072$ pada $\mathrm{P}_{1}, \mathrm{P}_{2}$, dan $\mathrm{P}_{3}$ secara berturut-turut $(\mathrm{p}=0,008)$. Berdasarkan hasil tersebut, dapat disimpulkan bahwa pemberian krim AT mampu memperlambat pembentukan keriput dan menurunkan kadar MMP-1 pada kulit punggung mencit jantan galur Balb/c yang dipajan sinar UVB.
\end{abstract}

Kata kunci: Keriput, krim asam traneksamat, matriks metaloproteinase-1, sinar ultraviolet B

\section{The Effect of Tranexamic Acid Cream on Wrinkle Formation and Matrix Metalloproteinase-1 Levels on Male Balb/c Mice Skin Exposed to Ultraviolet B Radiations}

\begin{abstract}
Oral tranexamic acid (TXA) has been proven to ameliorate wrinkle induced by skin dryness in hairless mouse. However, the equal human oral dose is too high and can induce toxicity if used in long term, and study of topical preparations for wrinkle treatment is limited. Therefore, this study was conducted using topical preparations as an alternative for oral treatment to examine the effects of TXA cream in wrinkle formation. Four weeks old of twenty-four male Balb/c mice, divided into four groups, then $3 \%$, $4 \%$ and 5\% TXA cream were administered on the back skin of mice in each group shortly after ultraviolet B (UVB) exposure, except for control group that only exposed to UVB lights without given any TXA creams. Wrinkle formation and matrix metalloproteinase (MMP-1) level were observed after 10 weeks of treatments. There were significant differences of wrinkle score, with mean value were $2.1 \pm 0.105$ for control group, $1.1 \pm 0.167$ for $3 \%$ and $4 \%$ groups, and $1.3 \pm 0.211$ for $5 \%$ group $(\mathrm{p}=0.005)$. There were also significant differences of MMP-1, with mean value were $0.75 \pm 0.08$ for control group, $0.54 \pm 0.033$, $0.40 \pm 0.052$, and $0.54 \pm 0.072$ for $3 \%, 4 \%$ and $5 \%$ group, respectively $(\mathrm{p}=0.008)$. Based on significant differences of wrinkle score and MMP-1 level, it can be concluded that administration of TXA cream may able to delay wrinkle formation and reduce the MMP-1 level on the mice skin exposed to ultraviolet B.
\end{abstract}

Keywords: Matrix metalloproteinase-1, tranexamic acid, ultraviolet B, wrinkle

Korespondensi: Andrew Citrawan, dr. Program Studi Magister Anti-Aging dan Aesthetic Medicine Fakultas Kedokteran, Universitas Padjajaran, Bandung, Jawa Barat 40161, Indonesia, email: andrew.citrawan@gmail.com Naskah diterima: 23 September 2018, Diterima untuk diterbitkan: 24 Juni 2019, Diterbitkan: 28 Juni 2019 


\section{Pendahuluan}

Kulit merupakan organ terluas tubuh manusia, meliputi sekitar $15 \%$ berat badan pada orang dewasa. ${ }^{1}$ Secara alami, manusia mengalami proses penuaan dengan bertambahnya usia. Ada dua macam faktor dominan yang merupakan penyebab terjadinya penuaan, yaitu faktor intrinsik seperti genetik, metabolisme selular, hormon, dan proses-proses metabolik lainnya, serta faktor ekstrinsik seperti pajanan pada sinar UV, merokok, polusi, dan toksin., ${ }^{2,3}$ Pajanan terus-menerus dari sinar UV mengakibatkan gangguan pada struktur normal kulit dan menyebabkan terjadinya photoaging prematur. ${ }^{4}$ Secara klinis, kulit yang mengalami penuaan akibat pajanan sinar UV ditandai dengan adanya hiperpigmentasi, kekeringan kulit, telangiektasia, permukaan kulit yang kasar, dan keriput. ${ }^{3}$

Berdasarkan panjang gelombangnya, sinar UV terbagi menjadi tiga macam, yaitu UVA (315-400 nm), UVB (290-320 nm), dan UVC (100-280 nm). UVC tidak mencapai permukaan kulit sebab terhalang pada lapisan ozon. ${ }^{5}$ Semakin besar panjang gelombang sinar UV, akan semakin dalam penetrasinya ke dalam kulit, tetapi mempunyai toksisitas yang lebih minimal terhadap DNA sel. Dengan demikian, UVA akan menembus lebih dalam pada lapisan kulit, tetapi kurang toksik jika dibandingkan UVB. Di sisi lain, UVB hanya mencapai lapisan epidermis, namun dengan toksisitas yang lebih besar terhadap DNA sel kulit. $^{6}$

Pajanan sinar UV pada kulit berakibat pada peningkatan ekspresi matriks metaloproteinase (MMP). ${ }^{7}$ MMP yang terbentuk selanjutnya akan mengakibatkan degradasi protein-protein di matriks ekstraselular (MES) seperti kolagen, fibronektin, elastin, dan proteoglikan, yang pada akhirnya akan menyebabkan terjadinya photoaging. ${ }^{8,9}$ MMP yang terbentuk akibat pajanan sinar UV pada awalnya diekspresikan dalam bentuk inaktif yang dikenal sebagai zymogen (pro-MMP), dan akan dapat bekerja setelah diaktifkan oleh enzim serin protease seperti plasmin atau molekul MMP lainnya. Plasmin merupakan enzim yang berperan penting pada proses aktivasi pro-MMP menjadi MMP, dan berasal dari aktivasi plasminogen dengan bantuan enzim plasminogen activator (PA). Terdapat dua macam PA, yakni tissue plasminogen activator (tPA) dan urokinase plasminogen activator (uPA). tPA memiliki peran utama pada proses fibrinolisis, sedangkan uPA utamanya bekerja pada proses proteolisis ekstraselular. ${ }^{10}$

Asam traneksamat (AT) merupakan suatu obat antifibrinolitik sintetik yang bekerja dengan cara menghambat daerah pengikat lisin pada molekul plasminogen, sehingga tidak terjadi aktivasi plasminogen, ${ }^{11}$ kemudian akan menghambat proses aktivasi molekul pro-MMP menjadi MMP, dan pada akhirnya mencegah terjadinya proses degradasi protein pada MES. Indikasi umum penggunaan AT adalah untuk pencegahan dan pengobatan perdarahan, ${ }^{12}$ akan tetapi, AT juga digunakan sebagai agen pencerah kulit dalam bidang kosmetik. ${ }^{13,14}$ Efek AT sebagai pencerah kulit pertama kali ditemukan oleh Nijo di Jepang pada tahun 1979, saat digunakan pada pasien dengan urtikaria kronik. ${ }^{15}$ Pemberian AT oral dengan dosis $750 \mathrm{mg} / \mathrm{kgBB}$ juga telah terbukti dapat mengurangi keriput akibat kulit kering, menurunkan kadar MMP-1, meningkatkan kandungan kolagen, menurunkan proliferasi sel mast, dan meningkatkan proliferasi sel fibroblas pada mencit hairless tipe Naruto Research Institute Otsuka Atrichia (NOA). ${ }^{16}$ Namun, pemberian AT per oral dengan dosis tinggi dalam jangka waktu yang lama dapat menimbulkan gejala toksisitas pada manusia sehingga perlu dicari sediaan alternatif lain berupa sediaan AT topikal. Penelitian ini bertujuan untuk menganalisis efek pemberian krim AT terhadap pembentukan keriput dan kadar MMP-1 pada kulit punggung mencit yang dipajan sinar UVB. 


\section{Metode}

Penelitian ini merupakan sebuah penelitian eksperimental laboratorik dengan rancang acak lengkap. Pada penelitian ini, digunakan dua puluh empat mencit (Mus musculus) jantan galur Balb/c usia 4 minggu yang diperoleh dari Laboratorium Biofarma Bandung, Indonesia. Selanjutnya, pemeliharaan mencit dilakukan di Laboratorium Farmakologi dan Terapi, Fakultas Kedokteran Universitas Padjadjaran, Bandung. Penelitian mulai dilakukan setelah mendapatkan persetujuan dari Komisi Etik Penelitian Universitas Padjadjaran Bandung dengan nomor 61/UN6.KEP/EC/2018 yang diterbitkan pada tanggal 19 Februari 2018.

Setiap ekor mencit ditempatkan pada kandang terpisah berukuran $17 \times 17 \times 10 \mathrm{~cm}$ dengan ventilasi ruangan yang baik, siklus cahaya 12 jam gelap-12 jam terang, dan diadaptasikan selama tujuh hari sebelum diberikan perlakuan. Makanan dan minuman diberikan ad libitum. Mencit dibagi menjadi empat buah kelompok secara acak, sehingga didapatkan enam ekor mencit pada masingmasing kelompok. Satu kelompok merupakan kontrol yang hanya diberikan pajanan sinar UVB saja tanpa diberikan krim AT. Tiga kelompok lainnya adalah kelompok perlakuan yang mendapatkan pajanan sinar UVB dan diberikan krim AT dengan konsentrasi 3\% $\left(\mathrm{P}_{0}\right)$, $4 \%\left(\mathrm{P}_{1}\right)$, dan 5\% $\left(\mathrm{P}_{3}\right)$.

Krim diberikan dengan dosis $0,1 \mathrm{~g} / \mathrm{cm}^{2}$, segera setelah pajanan UVB, setiap hari, selama
10 minggu. Pajanan sinar UVB dilakukan menggunakan lampu UVB Kernel KN-4003 dengan lampu narrow band merk Philips PL-S 9E/01-02 dengan panjang gelombang $311 \mathrm{~nm}$. Sebelum dilakukan pajanan, rambut bagian punggung mencit dicukur dengan luas $2 \times 2 \mathrm{~cm}$ menggunakan clipper elektrik dan gunting. Kulit punggung mencit yang telah dicukur selanjutnya dipajan dengan lampu UVB dengan jarak penyinaran $3 \mathrm{~cm}$, durasi selama 100 detik, dan dosis $166 \mathrm{~mJ} / \mathrm{cm}^{2}$, tiga kali seminggu, selama 10 minggu pada semua kelompok perlakuan. Total dosis yang diterima oleh setiap mencit adalah $4,98 \mathrm{~J} / \mathrm{cm}^{2}$.

Setelah sepuluh minggu, dilakukan penilaian skor keriput pada kulit punggung mencit dengan menggunakan metode Bisett, yaitu: 0: tidak ada keriput; 1: keriput kasar dangkal dan dinamis; 2: keriput kasar dangkal dan permanen; dan 3: keriput kasar dalam dan permanen. ${ }^{17}$ (Gambar 1). Setelah dilakukan penilaian keriput, selanjutnya mencit diberikan Ketamin dengan dosis $125 \mathrm{mg} / \mathrm{kgBB}$ secara intramuskular (IM) untuk persiapan biopsi eksisi kulit punggung mencit dengan luas $2 \times 1 \mathrm{~cm}$ dan proses sacrifice. Proses biopsi eksisi ini dilakukan setelah 24 jam pascapajanan sinar UVB terakhir. Eksisi kulit dilakukan pada lapisan epidermis hingga subkutan, kemudian dimasukkan ke dalam mikrotube, dan selanjutnya disimpan pada kotak yang berisikan es kering. Hasil biopsi kulit yang telah selesai dibawa ke Laboratorium Sentral, Jatinangor, Sumedang, untuk disimpan pada
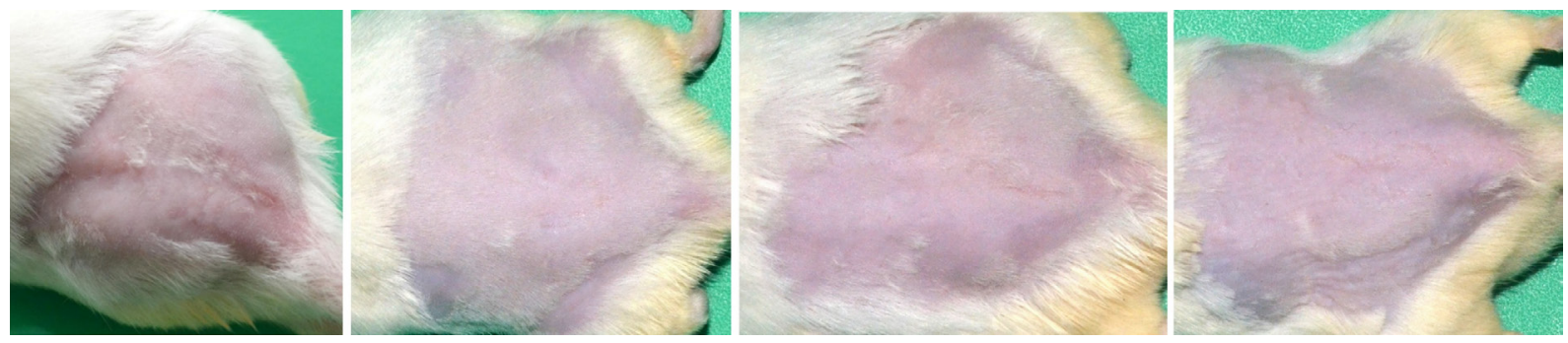

Gambar 1 Keriput Kulit Punggung Mencit pada Kelompok Kontrol $\left(\mathbf{P}_{0}\right)$, Kelompok AT 3\% $\left(\mathbf{P}_{1}\right)$, AT 4\% $\left(P_{2}\right)$, dan AT 5\% $\left(P_{3}\right)$ (Kiri ke Kanan)

Catatan: Terlihat penampilan keriput yang lebih kasar pada kelompok kontrol dibandingkan kelompok $\mathrm{P}_{1}, \mathrm{P}_{2}$, dan $\mathrm{P}_{3}$. 
suhu $-80^{\circ} \mathrm{C}$ untuk persiapan ekstraksi protein pada keesokan harinya.

Untuk persiapan pembuatan lisat, semua sampel penelitian ditimbang dengan berat $25 \pm 1 \mathrm{mg}$, kemudian dilakukan chopping dan penambahan lisis buffer sebanyak $20 \mathrm{uL} /$ mg jaringan. Selanjutnya, dilakukan proses homogenisasi menggunakan homogenizer dan disentrifugasi pada $17.000 \mathrm{G}$ selama 5 menit untuk memperoleh bagian supernatan. Bagian supernatan dipisahkan pada mikrotube baru, ditambahkan lisis dan sampel buffer, lalu dipanaskan pada suhu $95^{\circ} \mathrm{C}$ selama 5 menit, dan didinginkan di atas ice pack. Lalu setelah dingin, dilakukan pengambilan sebanyak $10 \mathrm{uL}$ sampel untuk dimasukkan ke dalam setiap well pada TRIS-SDS page gel dan dielektroforesis pada 80 volt (V) selama 20 menit, dilanjutkan dengan $100 \mathrm{~V}$ selama 2 sampai 2,5 jam. Setelah proses elektroforesis selesai, dilakukan transfer gel pada membran nitroselulosa dengan menggunakan transfer buffer, dan dielektroforesis kembali pada 200 miliampere (mA) selama 30 menit. Selanjutnya, membran nitroselulosa dicuci dengan air bersih dan dilakukan pewarnaan dengan menggunakan ponceau red selama \pm 1 menit, kemudian dicuci kembali dengan aquabidestilata dan Phosphate Buffer SalineTween 20 (PBST) 0,1\%, lalu diinkubasi dengan antibodi primer anti-MMP1 PA527210 (1:200; Thermo Fisher Scientific) selama satu malam pada suhu $4^{\circ} \mathrm{C}$. Pada hari selanjutnya, membran nitroselulosa dicuci kembali dengan PBST 0,1\% dan diinkubasi kembali menggunakan antibodi sekunder (anti-rabbit) selama 2 jam. Setelah inkubasi selama 2 jam, dilakukan pencucian kembali, lalu membran diletakkan di atas mesin WB Li-Cor dan diberikan substrat flourescene. Gambaran WB akan diperoleh dalam waktu 12 menit, seperti yang terlihat pada Gambar 2. Hasil WB lalu dikuantifikasi menggunakan software Image J.

Seluruh data analisis statistik disajikan dalam nilai rata-rata \pm standar deviasi di Tabel 1. Untuk perbandingan data antara kelompok perlakuan, data yang berdistribusi normal dan memiliki varian yang homogen dianalisis dengan menggunakan uji one-way ANOVA, lalu dilanjutkan dengan uji least significant difference (LSD). Namun, apabila data tidak berdistribusi normal dan mempunyai varian yang tidak homogen, maka digunakan uji Kruskal-Wallis dan dilanjutkan dengan uji lanjut Mann-Whitney. Semua hasil uji statistik dinyatakan bermakna jika nilai $\mathrm{p}<0,05$.

\section{Hasil}

Pada penelitian ini, terdapat perbedaan skor keriput yang bermakna pada kulit mencit yang dipajan sinar UVB dan diberikan krim AT dibandingkan kelompok kontrol yang hanya dipajan sinar UVB saja. Berdasarkan uji Kruskal-Wallis terhadap skor keriput, didapatkan nilai $p=0,005$. Nilai rata-rata skor keriput untuk kelompok kontrol adalah $2,1 \pm 0,105$, sedangkan nilai rata-rata skor keriput untuk kelompok perlakuan, $\mathrm{P}_{1}, \mathrm{P}_{2}$, dan $\mathrm{P}_{3}$ secara beturut-turut adalah $1,1 \pm 0,167$, $1,1 \pm 0,167$, dan $1,3 \pm 0,211$. Uji lanjut skor

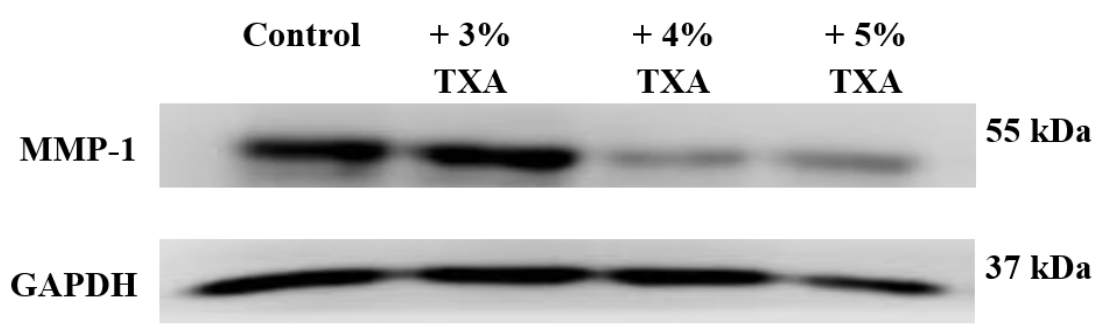

Gambar 2 Ekspresi Kadar Protein MMP-1 
Tabel 1 Skor Keriput dan Kuantifikasi Hasil WB MMP-1

\begin{tabular}{|c|c|c|}
\hline Kelompok Perlakuan & Skor Keriput & Kadar MMP-1 \\
\hline Kelompok $\mathrm{P}_{0}$ & $2,1 \pm 0,105$ & $0,75 \pm 0,080$ \\
\hline Kelompok $\mathrm{P}_{1}(\mathrm{AT} 3 \%)$ & $1,1 \pm 0,167$ & $0,54 \pm 0,033$ \\
\hline Kelompok $\mathrm{P}_{2}(\mathrm{AT} 4 \%)$ & $1,1 \pm 0,167$ & $0,40 \pm 0,052$ \\
\hline Kelompok $\mathrm{P}_{3}(\mathrm{AT} 5 \%)$ & $1,3 \pm 0,211$ & $0,54 \pm 0,072$ \\
\hline Nilai p & $0,005 *$ & $0,008 * *$ \\
\hline
\end{tabular}

keriput yang dilakukan untuk membandingkan kelompok yang menerima krim AT yaitu $\mathrm{P}_{1} /$ $\mathrm{P}_{2}, \mathrm{P}_{1} / \mathrm{P}_{3}$, dan $\mathrm{P}_{2} / \mathrm{P}_{3}$ semuanya memberikan nilai $p>0,05$. Grafik skor keriput dapat dilihat pada Gambar 3.

Pemberian krim AT pada kulit punggung mencit juga mampu menurunkan kadar MMP-11. Hasil ini sejalan dengan skor keriput yang diamati. Setelah normalisasi dengan menggunakan glyceraldehyde 3-phosphate dehydrogenase (GAPDH), diperoleh hasil nilai rata-rata kadar MMP-1 sebagai berikut: $0,75 \pm 0,080$ untuk kelompok kontrol $\left(\mathrm{P}_{0}\right)$; $0,54 \pm 0,033$ untuk kelompok $\mathrm{P}_{1} ; 0,40 \pm 0,052$ untuk kelompok $\mathrm{P}_{2}$; dan 0,54 $\pm 0,072$ untuk kelompok $\mathrm{P}_{3}$. Berdasarkan hasil uji one-way ANOVA, didapatkan nilai $\mathrm{p}=0,008$.

Berdasarkan hasil uji lanjut kadar MMP1 dengan menggunakan uji LSD, didapatkan nilai $\mathrm{p}=0,132$ untuk perbandingan kelompok $\mathrm{P}_{1}$ dan $\mathrm{P}_{2}$, nilai $\mathrm{p}=0,975$ untuk perbandingan kelompok $\mathrm{P}_{1}$ dan $\mathrm{P}_{3}$, dan nilai $\mathrm{p}=0,125$ untuk perbandingan kelompok $\mathrm{P}_{2}$ dan $\mathrm{P}_{3}$. Semua

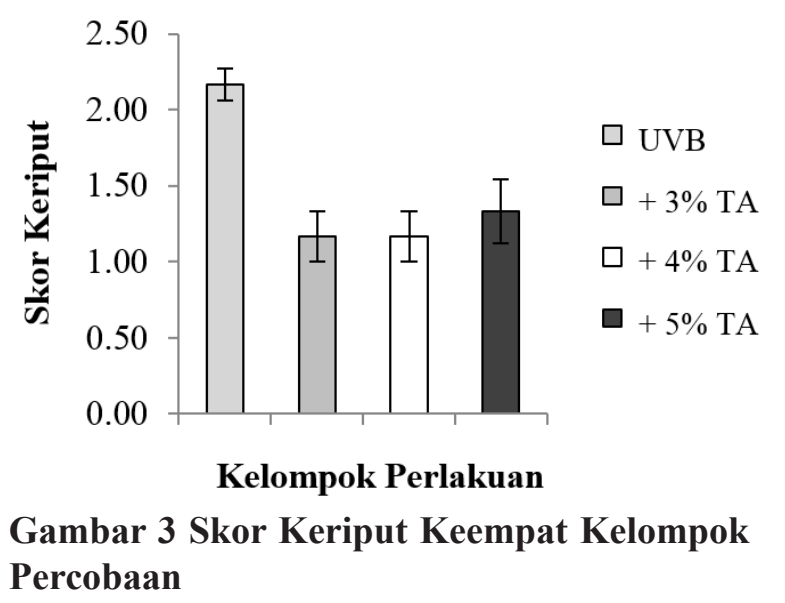

nilai $p$ tersebut $>0,05$, hal ini berarti bahwa tidak terdapat perbedaan kadar MMP-1 yang signifikan antara kelompok perlakuan yang mendapatkan krim AT 3\%, 4\%, maupun 5\%.

\section{Pembahasan}

Pajanan kronik sinar UVB mengakibatkan terbentuknya keriput pada kulit manusia. ${ }^{18}$ Terdapat banyak modalitas terapi dalam mencegah dan mengatasi keriput, ${ }^{2}$ salah satunya adalah AT. Berdasarkan penelitian sebelumnya, telah dibuktikan bahwa pemberian AT oral dapat megurangi pembentukan keriput dan menurunkan kadar MMP-1.16

Hasil penelitian ini menunjukkan bahwa terdapat perbedaan skor keriput dan kadar MMP-1 yang signifikan antara kelompok yang dipajan sinar UVB dan diberikan krim AT dibandingkan dengan kelompok kontrol yang hanya dipajan sinar UVB. Hal ini sejalan dengan hasil penelitian yang dilakukan oleh Hiramoto et al. di Universitas Suzuka, Jepang,

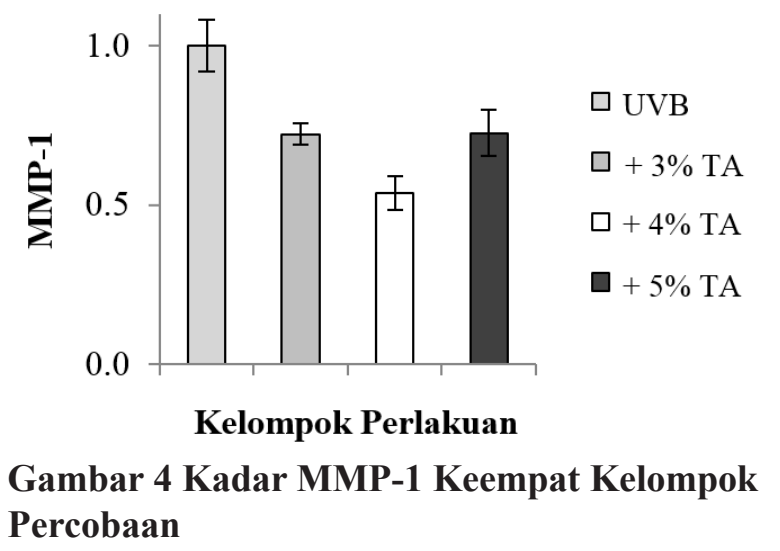


pada tahun 2016 dengan pemberian AT oral dengan dosis sebesar $750 \mathrm{mg} / \mathrm{kgBB} /$ hari pada mencit hairless tipe NOA.

Berdasarkan perhitungan statistik, terdapat penurunan skor keriput sebesar $47,62 \%$ pada kelompok yang diberikan krim AT 3\% dan 4\%, serta penurunan sebesar $38,1 \%$ pada kelompok yang diberikan krim AT 5\%, dibandingkan kelompok kontrol. Didapatkan pula penurunan kadar MMP-1 pada kulit mencit sebesar 28\% pada kelompok yang diberikan krim AT 3\% dan 5\%, serta penurunan kadar MMP-1 sebesar $46,67 \%$ pada kelompok yang diberikan krim AT 4\%, dibandingkan kelompok kontrol.

Asam traneksamat adalah suatu senyawa analog lisin yang bekerja dengan menempati lokasi pengikat lisin pada molekul plasmin dan plasminogen. ${ }^{11}$ Proses akvitasi plasminogen menjadi plasmin membutuhkan bantuan enzim plasminogen activator (PA), khususnya single chain u-PA. ${ }^{19}$ Plasminogen yang teraktivasi menjadi plasmin akan mengubah molekul pro-MMP menjadi MMP, termasuk MMP$1 .^{20}$ Pemberian AT topikal akan menghambat akvitas plasmin sehingga mencegah perlekatan molekul plasmin/plasminogen pada molekul pro-MMP, dan pada akhirnya menghambat MMP dalam mendegradasi protein di MES, seperti kolagen, fibronektin, elastin, serta proteoglikan. ${ }^{8}$ Penelitian ini menggunakan sediaan krim AT dengan konsentrasi sebesar $3 \%$, 4\%, dan 5\%. Hal ini sejalan dengan berbagai penelitian sebelumnya yang telah menggunakan krim AT dengan konsentrasi $2 \%$ hingga $5 \%$ untuk mengobati melasma dengan mekanisme kerja yang sama. ${ }^{14,21,22}$ Pada penelitian ini, krim AT diberikan segera setelah pajanan sinar UVB. Hal ini sejalan dengan metode penelitian yang dilakukan oleh Li et al. yang memberikan larutan AT $3 \%$ secara intradermal segera dilakukan pajanan sinar UVB. ${ }^{13}$ Biopsi kulit dilakukan setelah 24 jam pascapajanan UVB terakhir. Hal ini sejalan dengan hasil penelitian yang dilakukan oleh Takashima et al. mengenai akvititas PA setelah pajanan UVB. Pada penelitian tersebut, peningkatan produksi PA mulai terjadi pada 8 jam pertama pascapajanan sinar UVB, lalu meningkat secara drastis pada 16 jam pascapajanan dan terus bertambah hingga 48 jam pascapajanan. ${ }^{23}$

Pada penelitian ini, tidak ditemukan adanya tanda dan gejala efek samping berupa eritema atau iritasi kulit selama pajanan sinar UVB dan pemberian krim AT dengan konsentrasi sebesar 3\%, 4\%, dan 5\% pada kulit punggung mencit Balb/c setelah 10 minggu. Penilaian skor keriput dan kejadian eritema dilakukan hanya dengan pengamatan klinis disebabkan tidak tersedianya alat ukur atau software yang mampu menilai skor keriput secara objektif. Pada penelitian selanjutnya, diharapkan penilaian skor dapat menggunakan alat ukur atau software yang lebih objektif, seperti Visioline ${ }^{\circledR}$ VL650 (Quantirides) CourageKhazaka electronic GmbH, Jerman, yang dapat mengukur kedalaman, lebar, dan luas area keriput pada kulit serta Mexameter ${ }^{\circledR}$ MX18 untuk mengukur tingkat eritema pada kulit. Pada penelitian ini juga ditemukan bahwa tidak terdapat perbedaan skor keriput dan kadar MMP-1 yang signifikan antara kelompok yang diberikan krim AT 3\%, 4\%, maupun 5\%. Penelitian selanjutnya diharapkan menggunakan konsentrasi krim AT dengan rentang yang lebih luas agar dapat diketahui konsentrasi optimal dalam memperlambat pembentukan keriput dan penurunan kadar MMP-1 serta efek samping yang mungkin ditimbulkan pada konsentrasi maksimal.

Hasil penelitian ini menunjukkan bahwa krim AT dengan konsentrasi 3\%, 4\%, dan 5\% dapat menjadi salah satu modalitas terapi untuk memperlambat pembentukan keriput, tanpa disertai dengan adanya tanda-tanda iritasi seperti eritema kulit. Pemberian krim AT juga diharapkan dapat digunakan sebagai terapi adjuvan bersama dengan sediaan lain dalam memperlambat pembentukan keriput pada kulit. 


\section{Simpulan}

Pemberian krim AT dengan konsentrasi 3\%, $4 \%$, dan 5\% dapat memperlambat pembentukan keriput dan menurunkan kadar MMP-1 pada kulit mencit jantan galur Balb/c yang dipajan sinar UVB. Pemberian krim AT dengan ketiga konsentrasi selama 10 minggu pada penelitian ini juga tidak menunjukkan adanya tandatanda iritasi kulit seperti eritema.

\section{Pendanaan}

Penelitian ini tidak mendapatkan bantuan dana dari pihak manapun.

\section{Konflik Kepentingan}

Seluruh penulis menyatakan tidak terdapat potensi konflik kepentingan dengan penelitian, kepenulisan (authorship), dan atau publikasi artikel ini

\section{Daftar Pustaka}

1. Kolarsic PAJ, Kolarsick MA, Goodwin C. Anatomy and physiology of the skin. J Dermatol Nurses Assoc. 2011;3(4):20113. doi: 10.1097/JDN.0b013e3182274a98

2. Ganceviciene R, Liakou AI, Theodoridis A, Makrantonaki E, Zouboulis CC. Skin Anti-aging strategies. Dermatoendocrinol. 2012;4(3):308-19. doi: 10.4161/derm.22 804

3. Manriquez JJ, Majerson GD, Nicklas DC. Wrinkles. BMJ Clin Evid. 2008;1711-52.

4. Pittayapruek P, Meephansan J, Prapapan O, Komine M, Ohtsuki M. Role of Matrix Metalloproteinase in photoaging and photocarcinogenesis. Int $\mathrm{J}$ Mol Sci. 2016;17(6):1-20. doi: 10.3390/ijms1706 0868 .

5. Amaro-Ortiz A, Yan B, D'Orazio JA. Ultraviolet radiation, aging and the skin: Prevention of damage by topical cAMP manipulation. Molecules. 2015;19(5):6202 -19. doi: 10.3390/molecules19056202.

6. Sklar LR, Almutawa F, Lim HW, Hamzavi I. Effects of ultraviolet radiation, visible light, and infrared radiation on erythema and pigmentation: A review. Photochem Photobiol Sci. 2013;12(1):54-64. doi: 10. 1039/c2pp25152c.

7. Fisher GJ, Quan T, Purohit T, Shao Y, Cho MK, He T, Varani J, Kang S, Voorhees JJ. Collagen fragmentation promotes oxidative stress and elevates matrix metalloproteinase-1 in fibroblasts in aged human skin. Am J Pathol. 2009; 174(1):101-14. doi: 10.2353/ajpath.2009 .080599 .

8. Quan T, Qin Z, Xia W, Shao Y, Voorhees JJ, Fisher GJ. Matrix-degrading metalloproteinase in photoaging. J Investig Dermatol Symp Proc. 2009;14(1):20-4. doi: 10.1038/jidsymp.2009.8.

9. Kim J, Lee CW, Kim EK, Lee SJ, Park NP, Kim HS, et al. Inhibition effect of Gynura procumbens extract on UVBinduced matrix-metalloproteinase expression in human dermal fibroblasts. J Ethnopharmacol. 2011;137(1):427-33. doi: 10.1016/j.jep.2011.04.072.

10. Schaller J, Gerber SS. The plasminantiplasmin system: structural and functional aspects. Cell Mol Life Sci. 2011;68(5): 785-801. doi: 10.1007/s00018-010-0566 -5 .

11. Klak M, Anakkala N, Wang W, Lange S, Jonsson IM, Tarkowski A, et al. Tranexamic acid, an inhibitor of plasminogen activation, aggravates staphylococcal septic arthritis and sepsis. Scand J Infect Dis. 2010;42(5): 351-8. doi: 10.3109/00365540903510690

12. Ng W, Jerath A, Wasowicz M. Tranexamic acid: A clinical review. Anaesthesiol Intensive Ther. 2015;47(4):339-50. doi: 10. 5603/AIT.a2015.0011

13. Li D, Shi Y, Li M, Liu J, Feng X. Tranexamic acid can treat ultraviolet 
radiation-induced pigmentation in guinea pigs. Eur J Dermatol. 2010;20(3):289-92. doi: 10.1684/ejd.2010.0912.

14. Poojary S, Minni K. Tranexamic acid in melasma: A review. J Pigment Disord. 2015;2:228. doi: 10.4172/2376-0427.100 0228

15. Tse TW, Hui E. Tranexamic acid: An important adjuvant in the treatment of melasma. J Cosmet Dermatol. 2013;12(1): 57-66. doi: 10.1111/jocd.12026.

16. Hiramoto K, Sugiyama D, Takahashi Y, Mafune E. The amelioration effect of tranexamic acid in wrinkles induced by skin dryness. Biomed Pharmacother. 2016;80:16-22. doi: 10.1016/j.biopha.201 6.02.013.

17. Kim YG, Sumiyoshia M, Sakanaka M, Kimura Y. Effects of ginseng saponins isolated from red ginseng on ultraviolet B-induced skin aging in hairless mice. Eur J Pharmacol. 2009;602(1):148-56. doi: 10.1016/j.ejphar.2008.11.021.

18. Seité S, Fourtanier A, Moyal D, Young AR. Photodamage to human skin by suberythemal exposure to solar ultraviolet radiation can be attenuated by sunscreens: A review. Br J Dermatol. 2010;163(5): 903-14. doi: 10.1111/j.1365-2133.2010.1 0018.x.
19. Santibanez JF. Urokinase type plasminogen activator and the molecular mechanisms of its regulation in cancer. Protein Pept Lett. 2017;24(10):936-46. doi: 10.2174/09298 66524666170818161132.

20. Iyer RP, Patterson NL, Fields GB, Lindsey ML. The history of matrix metalloproteinases: Milestones, myths, and misperceptions. Am J Physiol Heart Circ Physiol. 2012;303(8):H919-30. doi: 10.11 52/ajpheart.00577.2012.

21. Ebrahimi B, Naeini FF. Topical tranexamic acid as a promising treatment for melasma. $\mathrm{J}$ Res Med Sci. 2014;19(8):753-7.

22. Kanechorn NAP, Niumphradit N, Manosroi A, Nakakes A. Topical 5\% tranexamic acid for the treatment of melasma in Asians: A double-blind randomized controlled clinical trial. J Cosmet Laser Ther. 2012;14(3):1504. doi: 10.3109/14764172.2012.685478.

23. Hiramoto K, Yamate Y, Sugiyama D, Takahashi Y, Mafune E. Tranexamic acid suppresses ultraviolet B eye irradiationinduced melanocyte activation by decreasing the levels of prohormone convertase 2 and alpha-melanocyte-stimulating hormone. Photodermatol Photoimmunol Photomed. 2014;30(6):302 -7. doi: 10.1111/phpp.12 131 